\title{
Precipitin Reactions between Insulin, Proinsulin, Insulin Chains and Insulin Antibody
}

\author{
D.D. Bansal, J.H. Connolly and J. Vallance-Owen \\ Departments of Medicine and Microbiology, The Queen's University of Belfast, Ireland \\ Received: January 15, 1973, and in revised form: May 11, 1973
}

Summary. Insulin antibody was produced in guinea pigs and the precipitins tested by double diffusion in agarose gel. Pork, beef and monocomponent insulin produced precipitin lines. Proinsulin also produced a precipitin line with these antisera but no lines appeared with either the A-chain or the B-chain of insulin. There was good correlation between the precipitin titre and the radioinamunoassay titre.

Key words: A-chain, B-chain, guinea, pig, antibody, insulin, precipitin reaction, proinsulin, radioimmunoassay.
The immunoprecipitin reaction between insulin and insulin antibody was first studied by Lerman [1]. Although the formation of visible precipitin lines between insulin and insulin antibody has been demonstrated by several workers $[2,3,4,5,6]$, some recent reports have doubted this $[7,8,9]$. These conflicting reports prompted us to re-examine this problem.

\section{Materials and Methods}

Commercial Actrapid pork insulin (prepared from 5 -times recrystallised insulin), 10-times recrystallised pork insulin and Actrapid monocomponent (MC) pork insulin were kindly donated by Novo, and beef proinsulin was obtained from Eli Lilly \& Co. Beef insulin and sulfonated beef B-chain of insulin were obtained from the Boots Pure Drug Co Ltd. Oxidised A-chain of insulin was prepared from pork insulin by Sanger's method [10].

\section{Immunisation}

Guinea pigs were immunised with commercial Actrapid pork insulin mixed with Freund's adjuvant.

\section{Antibody titrations}

The titre of the three selected antisera used in this study was determined by using a radioimmunoassay of insulin in which separation was carried out by the dextran. coated charcoal method [11]. About $200 \mathrm{pg}$ of labelled pork insulin was incubated overnight in a total volume of $0.3 \mathrm{ml}$ at $4^{\circ} \mathrm{C}$. The antigen as well as antiserum was diluted with $0.04 \mathrm{M}$ phosphate buffer ( $\mathrm{pH} 7.4$ ) containing $2 \%$ horse serum. The final dilution of antiserum was $1 / 3$. The dilution of antiserum which binds $50 \%$ of the antigen was defined as the titre of the antibody.

\section{Precipitin tests}

Veronal buffer ( $\mathrm{pH}$ 8.3) was used for all dilutions and for the preparation of $0.9 \%$ agarose gel. The multiple well double diffusion technique of Ouchterlony [12] was used with the outer wells being charged twice, before and after an interval of $2 \mathrm{~h}$; only then was the centre well filled.

\section{Results}

The antibody titres of the antisera used are shown in Table 1.
Table 1. Antibody titres

\begin{tabular}{|c|c|c|}
\hline Antiserum & Reciprocal of antib & itre \\
\hline (GP No) & radioimmunoassay & precipitin \\
\hline 46 & 166.000 & 8 \\
\hline 48 & 60.000 & 2 \\
\hline 51 & 25.000 & 1 \\
\hline
\end{tabular}

1.5 units of pork insulin per $\mathrm{ml}$ was used to determine precipitin titres.

The results of the antigen-antibody precipitin reactions are shown in Fig. 1 and Table 2. Antisera from guinea pigs 46 and 48 produced two precipitin lines with pork as well as beef insulin, whereas guinea pig 51 showed only one precipitin line. Monocomponent insulin also produced two lines but proinsulin produced only one precipitin line. No lines were obtained either with A-chain or B-chain of insulin, even at a concentration of $1 \mathrm{mg} / \mathrm{ml}$. The precipitin line formed by proinsulin fused with one of the two lines produced by insulin using antisera 46 and 48 .

\section{Discussion}

The study confirms that pork insulin, when used as an immunising antigen, produces insulin-precipitating antibodies. These results also show that there is a good correlation between precipitin and the radioimmunoassay titres. Those workers $[7,8,9]$ who were unable to get precipitin lines may not have had an antiserum of sufficiently high titre. The fact that precipitin lines were produced by beef insulin with these antisera suggests that a difference of two amino acid residues at positions 8 and 10 of the A-chain of pork and beef insulins does not affect the precipitin reaction.

Our studies show that an intact insulin molecule is necessary to produce visible precipitin lines as neither the A-chain nor the B-chain alone has sufficient determinant sites to give a precipitin reaction [13]. Neither A-chain nor B-chain reacts with insulin antisera in radioimmunoassays [14], but proinsulin does react [15]. 
The fact that proinsulin also formed a precipitin line which fused with one of the insulin precipitin lines shows that there is an antigen common to these two substances and their tertiary structures do not affect the precipitin reaction. The formation of two precipitin lines by MC insulin as well as pork and beef insulin suggests that these preparations contain another antigen which may be proinsulin, whereas proinsulin in itself is a single component. We have not tested the C-peptide antibodies in these antisera but assume that
2. Birkinshaw, V.J., Randall, S.S., Risdall, P.C.: Formation of precipitin lines between insulin and antiinsulin serum produced in sheep and in guinea pigs. Nature (Lond.) 193, 1089-1090 (1962)

3. Jones, V.E., Cuncliffe, A.C.: A precipitating antibody to insulin. Nature (Lond.) 192, $136-138$ (1961)

4. Moloney, P.J., Aprile, M.A.: On the antigenicity of insulin: flocculation of insulin-anti-insulin. Canad. J. Biochem. 37, 793-800 (1959)

5. Schaeg, W., Finger, H.: Evidence for the precipitating activity of insulin antibodies. Experientia (Basel) 23, $951-952(1967)$
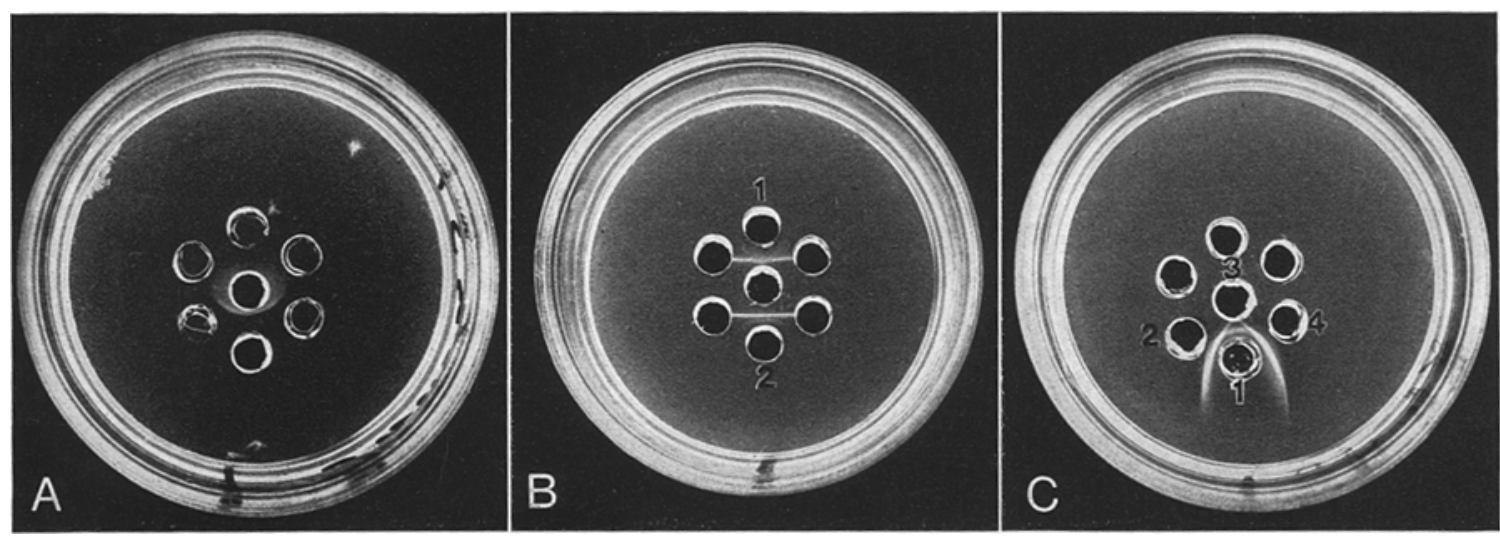

Fig. 1. A) Precipitin line between antiserum from GP 51 and pork insulin. B) Precipitin lines between antiserum from GP 46 and pork MC insulin. Central well first charged with antiserum and after $3 \mathrm{~h}$ wells 1 and 2 were charged with pork MC insulin. C) Precipitin lines between antiserum from GP 48 (1) and pork insulin (2), proinsulin (3) and beef insulin (4)

Table 2. Antigen-Antibody Precipitin Reactions

\begin{tabular}{|c|c|c|c|c|c|c|}
\hline $\begin{array}{l}\text { Antiserum } \\
\text { (GP No) }\end{array}$ & $\begin{array}{l}\text { Pork insulin } \\
\text { (units/ml) }\end{array}$ & $\begin{array}{l}\text { Beef insulin } \\
\text { (units/ml) }\end{array}$ & $\begin{array}{l}\text { Actrapid } \\
\text { MC pork } \\
\text { insulin } \\
\text { (units/ml) }\end{array}$ & $\begin{array}{l}\text { Beef } \\
\text { proinsulin } \\
(\mathrm{mg} / \mathrm{ml})\end{array}$ & $\begin{array}{l}\text { Pork } \\
\text { A-chain } \\
(\mathrm{mg} / \mathrm{ml})\end{array}$ & $\begin{array}{l}\text { Beef } \\
\text { B-chain } \\
(\mathrm{mg} / \mathrm{ml})\end{array}$ \\
\hline 46 & $\frac{++}{(1.5)}$ & $\frac{++}{(1.5)}$ & $+\frac{+}{(1.5)}$ & $\stackrel{+}{(0.25)}$ & $\overline{(0.125-1)}$ & $\overline{(0.125-1)}$ \\
\hline 48 & $\begin{array}{l}+t+ \\
(1.5)\end{array}$ & $\frac{+t}{(1.5)}$ & $\begin{array}{l}++ \\
(1.5)\end{array}$ & & & $(0.125-1)$ \\
\hline 51 & $+(1.5)$ & $+(1.5)$ & $(1.5)$ & + & & $(0.125-1)$ \\
\hline
\end{tabular}

Concentration of antigen used is given in parentheses.

$+\quad=$ one precipitin line

$+t=$ two precipitin lines

$-\quad=$ no precipitin line

C-peptide antibodies will not give precipitin reaction as neither the A-chain antisera nor the B-chain antisera gives this reaction [16].

Acknowledgement. We wish to thank the British Diabetic Association for financial support.

\section{References}

1. Lerman, J.: Insulin resistance. The role of immunity in its production. Amer. J. med. Sci. 207, 354-360 (1944)
6. Ziegler, M., Lipmann, H. G. : Gewinnung präzipitierender Insulin-Antikörper von der Ziege caper domesticus. Experientia (Basel) 25, 191 - 192 (1969)

7. Ceska, M.: Insulin-anti-insulin precipitates in the presence of various dextrans. Immunology 15, 837$843(1968)$

8. Heinzel, W., Grimminger, H., Kallee, E.: Precipitating insulin-anti-insulin complexes. Diabetologia 7, $204-205(1971)$

9. Humphrey, J.H., White, R.G.: In: Immunology for Students of Medicine, 2nd ed. 446. Oxford: Blackwell 1964

10. Sanger, F.: Fractionation of oxidised insulin. Biochem. J. 44, 126-128 (1949)

11. Herbert, V., Lau, K.S., Gottlieb, C. W., Bleicher, S.J.: Coated charcoal immunoassay of insulin. J: clin. Endocr. 25, 1375-1384: (1965) 
12. Ouchterlony, O.: Gel-diffusion techniques. In: Immunological Methods. P. 55-78. Oxford: Blackwell 1964

13. Wilson, S.: The antigenic loci in insulin. Proc. 6th Cong. Int. Diab. Fed. Stockholm 1967. Excerpta Medica Found. 403-405. Stockholm: Ostman 1969

14. Varandani, P.T.: Plasma concentrations of A and B chains of insulin in non-diabetic, diabetic and high risk potential diabetic subjects. Diabetes 17, 547-556 (1968)

15. Buchanan, K.D.: Unpublished observations

16. Bansal, D.D., Vallance-Owen, J.: Unpublished observations.

Prof. J. Vallance-Owen,

Department of Medicine,

Institute of Clinical Science

Grosvenor Road

Belfast BT/2 6BJ

Northern Ireland 